\title{
Chromosomal Variation of Osgoodomys banderanus (Rodentia: Muridae)*
}

\author{
Arturo Núñez-Garduño ${ }^{1}$, Ricardo López-Wilchis ${ }^{2}$ \\ and Fernando A. Cervantes ${ }^{3}$ \\ ${ }^{1}$ Facultad de Biología, Universidad Michoacana de San Nicolás de Hidalgo, \\ A. P. 2-10 Morelia, 58000 Michoacán, México \\ ${ }^{2}$ Departamento de Biología, Universidad Autónoma Metropolitana, \\ Ixtapalapa, A. P. 55-535 México 09340 D. F. \\ ${ }^{3}$ Colección Nacional de Mamíferos, Instituto de Biología, Universidad Nacional Autónoma de México, \\ A. P. 70-153 México 04510 D. F.
}

Accepted July, 7, 1999

\begin{abstract}
Summary Chromosomal material from 76 specimens of Osgoodomys banderanus collected in 22 different localities was studied. The revised material was obtained from femur bone marrow from individuals which were previously injected with colchicine. A minimum of 10 mitotic fields were studied for each specimen. A number $2 n=48$ was found for all the studied specimens. 3 different fundamental numbers and 4 different cytotypes were found 3 of them are not registered yet. Geographical distribution for each cytotype is presented. The $\mathrm{G}$ banding pattern was obtained and a cladogram with the possible chromosomal changes is presented.
\end{abstract}

Key words Chromosomes, Variation, Cytotypes, Geographical distribution, Osgoodomys.

Osgodoomys banderanus is a Mexican endemic murid (Hall 1981). It is present from the Southeast (state of Guerrero $15^{\circ} 20^{\prime} \mathrm{N}, 98^{\circ} 30^{\prime} \mathrm{W}$ ) throughout the Northwest (state of Nayarit $23^{\circ} \mathrm{N}$, $105^{\circ} 40^{\prime} \mathrm{W}$ ). It occurs at an elevation of $20-1500 \mathrm{~m}$ above sea level in a dry and hot climate, particularly, it inhabits rocky areas, also around the margins of streams which have rocky walls and are surrounded by various types of vegetation: tropical deciduous forest, subdeciduous forest, oak forests or secondary vegetation (Alvarez 1968, Núñez 1993).

From the taxonomical point of view, the genus has been subjected to various changes; it was described as a species within the genus Peromyscus by Allen (1897). Later, a subgenus of Osgoodomys was established (Hooper 1958, Hooper and Musser 1964). Carleton (1980) proposed a separation within the generic level of $O$. banderanus based upon phenotypic differences.

Lee and Elder (1977) and Rogers et al. (1984) reported a karyotype for O. banderanus, based only on the study of specimens from the Jalisco state which is just a small part of the total distribution area for this species. They described it as a relatively simple one, consisting of a pair of large chromosomes, two small biarmed and the rest of the karyotype made up of 20 pairs of acrocentric autosomes which exhibited various sizes from small to large. Another report does not indicate the geographic source of the material (Stangl Jr. and Baker 1984).

The studied taxon has been considered a relict species which was separated in early stages from the ancestral phyletic branch (Hooper 1968). Research by Linzey and Layne (1969) and Carleton (1989) have lead these authors to make a similar proposal.

Since $O$. banderanus is found in many diverse environments, it is possible that interpopulation variation could be detected by comparing the karyotypes for the different populations. Therefore,

* This work is part of the Doctoral Thesis in Biological Science of the first author. Universidad Autónoma Metropolitana, México.

E-mail: ${ }^{1}$ anunez@zeus.ccu.umich.mx. ${ }^{2}$ rlw@xanum.uam.mx. ${ }^{3}$ fac@ibiologia.unam.mx. 
the study of the karyotype of individuals collected at sites located throughout the geographic distribution area for this species, was carried out to test this possibility.

\section{Material and methods}

The chromosomic material was obtained from male and female individuals of Osgoodomys banderanus captured in 22 different localities and it was procesed in the field. A minimum of 10 mitotic fields were studied for each one of the specimens.

Chromosomic material for preparations was obtained from femur bone marrow (Dyer 1979, Baker et al. 1983). The specimens were injected intraperitoneally with a colchicine (Microlab) aqueous $0.004 \%$ solution at a rate of $0.1 \mathrm{ml} / 10 \mathrm{~g}$ of specimen weight, $45 \mathrm{~min}$ before samples of chromosomic material were obtained.

The conventional chromosome classes were established according to Levan et al. (1964). After chromosomic figures homologation, the number of autosomic arms was considered as the fundamental number (F.N.).

A comparison of the karyotypes obtained was carried out against the standard karyotype proposed for the genus by the Committee for standardization of chromosomes of Peromyscus (1977, 1994).

In order to obtain $\mathrm{G}$ bands, the technique proposed by Baker et al. (1987) was followed.

On the basis of the differences shown for the cytotypes found, a cladogram was integrated with the most parsimonious routes among the possible chromosome arms additions, following a similar pattern to that presented by Greenbaum and Baker (1978) and Baker et al. (1979).

The specimens with cytotype A, B, and D are stored in the Universidad Autónoma Metropolitana, Universidad Michoacana de San Nicolás de Hidalgo, Universidad Nacional Autónoma de Mexico, and Texas Tech University collections and the specimenes with cytotype $\mathrm{C}$ are stored in the collection of Facultad de Biología, Universidad Michoacana de San Nicolás de Hidalgo.

\section{Results}

Chromosomic material from 76 specimens (50 males, 26 females) was studied. Analysis of the results obtained for the karyotypes of the various populations of $O$. banderanus indicated that they could be arranged in four different cytotypes, all with a $2 n=48$ number, and a different fundamental number (Table 1, Figs. 1a, 2A-D). The cytotypes found are the following:

Cytotype A (47 specimens, $26 \hat{0}, 21$ \%). This cytotype has a chromosomic number $2 n=48$ and a F.N. $=52$ (Table 1, Figs. 1a, 2A). The biarmed were a pair of submetacentric chromosomes of small size and two pairs of subtelocentric chromosomes., (one pair of those was the biggest and the other pair was the smallest of the group); while the monorameous were 20 pairs of acrocentric chromosomes (sizes varying from large to small). The $\mathrm{G}$ bands pattern is presented in Fig. $1 \mathrm{~b}$.

Cytotype B (10 specimens, 60,4 ㅇ). This cytotype has a chromosomic number $2 \mathrm{n}=48$ and a F.N. $=52$ (Table 1, Figs. 1a, 2B). The biarmed chromosomes were a pair of metacentric (the smallest one) and two pairs of subtelocentric (the pairs of the largest sizes) while the monorameous were 20 pairs of acrocentric chromosomes (sizes varying from large to small). The $\mathrm{G}$ bands pattern is presented in Fig. $1 b$.

Table 1. Comparison of the found cytotypes in $O$. banderanus populations. $2 \mathrm{n}=$ diploid number, F.N. fundamental number, $\mathrm{M}=$ metacentric, $\mathrm{SM}=$ submetacentric, $\mathrm{ST}=$ subtelocentric, $\mathrm{A}=$ acrocentric, $\mathrm{X}$ and $\mathrm{Y}=$ sexual chromosomes

\begin{tabular}{ccccccccc}
\hline \hline Cytotype & 2n & F.N. & M & SM & ST & A & X & Y \\
\hline A & 48 & 52 & - & 1 & 2 & 20 & ST & A \\
B & 48 & 52 & 1 & - & 2 & 20 & ST & A \\
C & 48 & 62 & 2 & 1 & 5 & 15 & ST & A \\
D & 48 & 78 & 8 & 5 & 3 & 7 & ST & A \\
\hline
\end{tabular}




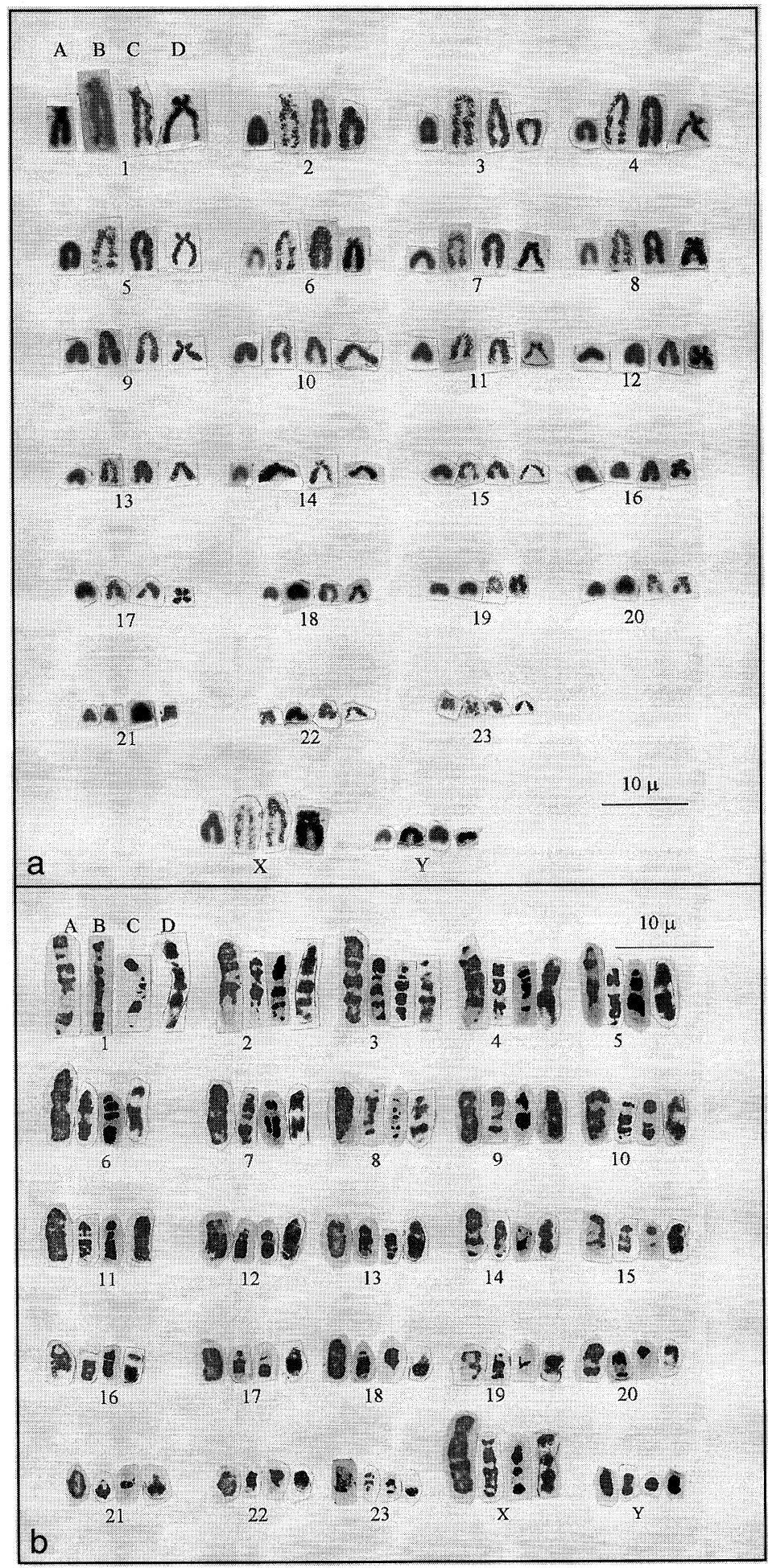

Fig. 1. a) Found cytotypes (A, B, C, D) in O. banderanus populations. b) G-band pattern of the same cytotypes A.-22=submetacentric; $1,23, \mathrm{X}=$ subtelocentric; $2-21, \mathrm{Y}=$ acrocentric. $\mathrm{b} .-23=$ metacentric; 1 , 2, $\mathrm{X}=$ subtelocentric; 3-22, $\mathrm{Y}=$ acrocentric. C.-21, $22=$ metacentric, $20=$ submetacentric; 1, 11, 14-16, $\mathrm{X}=$ subtelocentric; $2-10,12,13,17,19,23, \mathrm{Y}=$ acrocentric. D. $-4,9,12,16-20=$ metacentric; $2,7,8,11$, $13=$ submetacentric; $1,5,6, X=$ subtelocentric; $3,10,14,15,21-23, Y=$ acrocentric. 

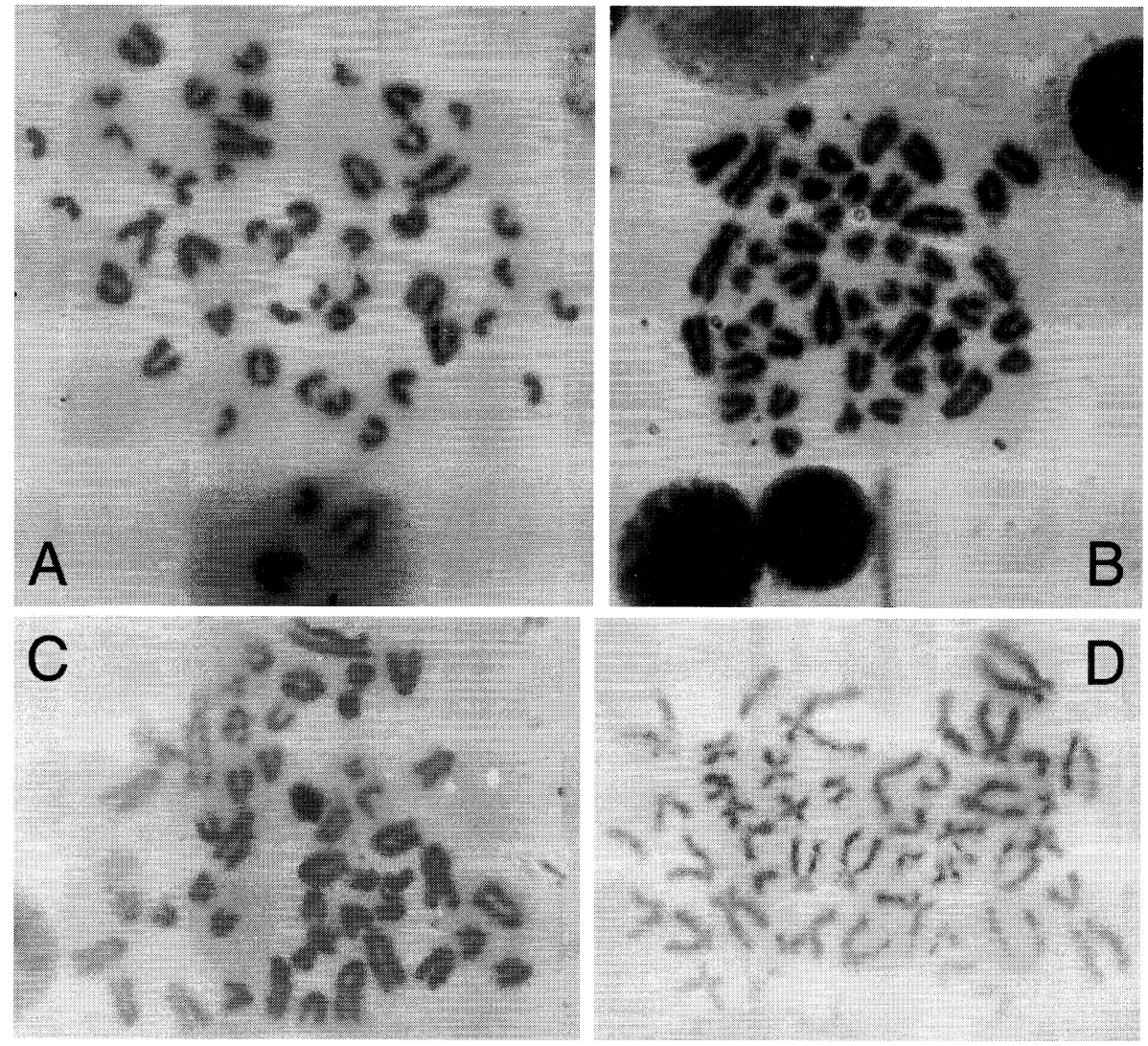

Figs. 2A-D. Cytotypes found (A, B, C, D) in populations of Osgoodomys banderanus.

Cytotype $\mathrm{C}$ ( 13 specimens, 60,7 \%). This cytotype has a chromosomic number $2 \mathrm{n}=48$ and a F.N. $=62$ (Table 1, Figs. 1a, 2C). The biarmed chromosomes were: two pairs of metacentric chromosomes of small size, one pair of submetacentric chromosomes of equally small size and five pairs of subtelocentric chromosomes (the one with the largest size and the other four of a medium size). The monorameous were 15 pairs of acrocentric chromosomes (sizes varying from large to small). The $\mathrm{G}$ bands pattern is presented in Fig. $1 b$.

Cytotype D (6 specimens, 30,3 o ). This cytotype has a chromosomic number $2 \mathrm{n}=48$ and a F.N. $=78$ (Table 1, Figs. 1a, 2D). The biarmed chromosomes were 8 pairs of metacentric chromosomes (sizes varying from large to small) five pairs of submetacentric chromosomes (sizes varying from large to medium) and three pairs of subtelocentric chromosomes (large size). The monorameous were seven pairs of acrocentric chromosomes (sizes varying from large to small). The $\mathrm{G}$ bands pattern is presented in Fig. $1 \mathrm{~b}$.

Comparative analysis of the $\mathrm{G}$ chromosome bands of the four cytotypes was carried out (Table 2). Cytotype A, which agrees with the one published by Stangl Jr. and Baker (1984) was compared with the other three cytotypes and it was found that cytotype B exhibits a repetition or duplication in chromosome 1, and a pericentric inversion in chromosome 2 , a deletion in chromosome 22 , and an addition in chromosome 23. Cytotype C, exhibits changes in chromosomes 12, 14-16, and 20, 21 which were additions and also changes in chromosomes 22 and 23 which were deletions. Cytotype $\mathrm{D}$ exhibited changes in chromosomes 1 and 2, where a repetition of bands was observed, also in chromosomes 4-9, 11-13, and 16-20 which were identified as addition cases. For chromosomes 22 and 23 , deletion was considered as a possibility. 
Chromosomic rearrangements were not observed in any of the 4 cytotypes for numbers 3,10 , and the sexual chromosomes.

Fig. 3 shows a proposed geographic distribution of the different cytotypes from the studied populations.

\section{Discussion}

The finding of 4 different cytotype modalities (Table 1, Fig. 1a, b) for $O$. banderanus contrasts with the findings reported by Lee and Elder (1977), Committee (1977), Greenbaum and Baker (1978), Baker et al. (1979) and Rogers et al. (1984). These authors all agree with one single karyotype for the species consisting of a group of acrocentric chromosomes except for chromosomes 1, 22, and 23 which are biarmed. This cytotype is the most common in the entire distribution area for this species (Fig. 3).

The 4 cytotypes have a number $2 n=48$ but 3 different fundamental numbers were found which agrees with Lawlor (1974) who claims that there are no fusion or centric fission which could reduce or increase the chromosome number.
Table 2. Probable chromosomic rearrengements registered by G-bands in the four cytotypes in $O$. banderanus.

\begin{tabular}{|c|c|c|c|}
\hline Cytotype A & Cytotype B & Cytotype C & Cytotype D \\
\hline \multicolumn{4}{|c|}{ Chromosome } \\
\hline 1 & Duplication & & Duplication \\
\hline 2 & $\begin{array}{l}\text { pericentric } \\
\text { Inversion }\end{array}$ & & Duplication \\
\hline 3 & & & \\
\hline 4 & & & Addition \\
\hline 5 & & & Addition \\
\hline 6 & & & Addition \\
\hline 7 & & & Addition \\
\hline 8 & & & Addition \\
\hline 9 & & & Addition \\
\hline 10 & & & \\
\hline 11 & & & Addition \\
\hline 12 & & Addition & Addition \\
\hline 13 & & & Addition \\
\hline 14 & & & Addition \\
\hline 15 & & & Addition \\
\hline 16 & & Addition & Addition \\
\hline 17 & & & Addition \\
\hline 18 & & & Addition \\
\hline 19 & & & Addition \\
\hline 20 & & Addition & Addition \\
\hline 21 & · & Addition & \\
\hline 22 & Deletion & Deletion & Deletion \\
\hline 23 & Addition & Deletion & Deletion \\
\hline $\mathrm{x}$ & & & \\
\hline $\mathrm{y}$ & & & \\
\hline
\end{tabular}

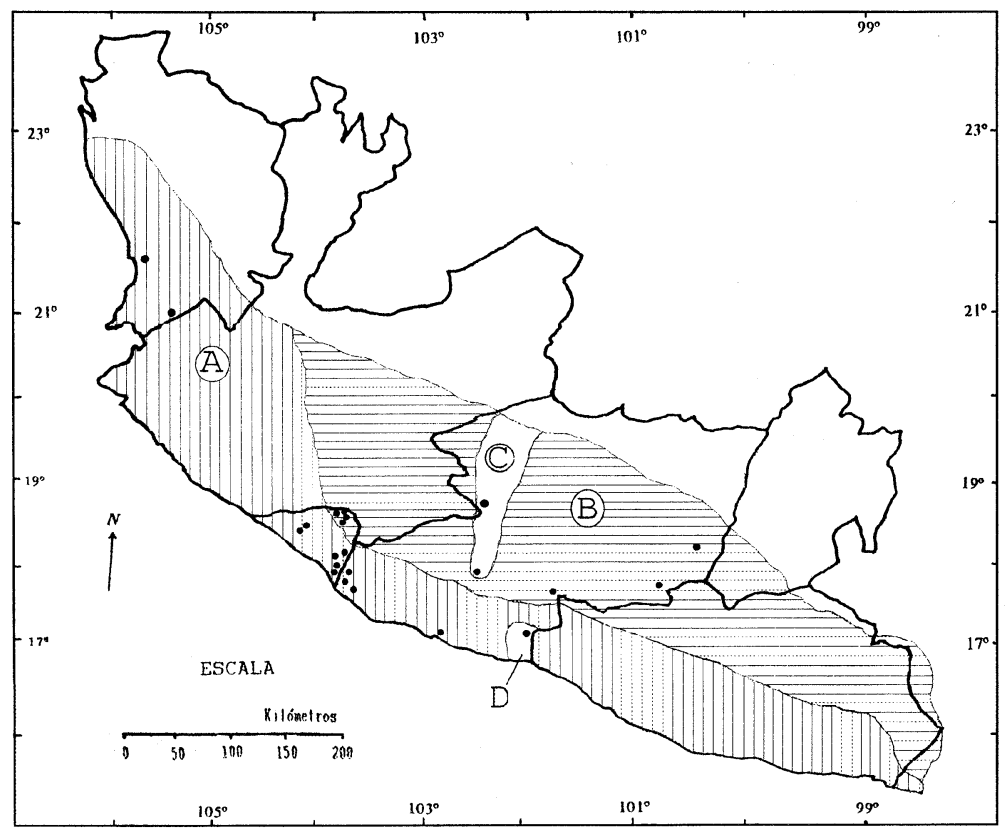

Fig. 3. Geographical distribution of the found cytotypes (A, B, C, D). Localities are shown in the map and cited in the text. 
Cytotype A exhibits autosomes and sex chromosomes which have the $\mathrm{G}$ chromosomic band pattern reported by Stangl Jr. and Baker (1984) for O. banderanus (Fig. 1b) and it was detected in O. banderanus specimens.

Cytotype B, this modality differs slightly from the cytotype A modality. In this work it was detected in $O$. $b$. vicinior specimens and exhibits the following probable chromosomic rearrangements: one repetition, one pericentric inversion, one deletion and one addition. (Tables 1, 2, Fig. 1b).

Cytotype $\mathrm{C}$, in this cytotype as well as in cytotype B, notable differences could be appreciated regarding the chromosome type. It exhibited an intermediate number of biarmed chromosomes (8) when compared to populations with the modalities of cytotypes A, B, and D and it presented as probable chromosomic rearrangements 6 additions and 2 deletions. (Tables 1, 2, Fig. 1b).

Cytotype D exhibits the following probable chromosomic rearrangements: 2 duplications, 14 additions and 2 deletions. The fundamental numbers indicate that the modality $\mathrm{D}$ karyotype is the population that presents the largest number of autosomic arms. (Tables 1, 2, Fig. 1b).

Due to the fact that the 4 karyotype modalities exhibit the same diploid number it is possible that Robertsonian changes did not occur. Rather, the probable chromosomic changes coincide with those reported in the literature (Hsu and Arrighi 1968, Arrighi et al. 1976, Greenbaum and Baker 1978, Yates et al. 1979). These authors suggest that the heterochromatin additions and pericentric inversions have played a prominent role in the Peromyscines evolution. Moreover, it has been reported that pericentric inversions have been important in the appearance of new populations within Peromyscines (Baker et al. 1979).

The presence of a karyotype which differs in the size of a biarmed chromosome (number 22 in cytotype A and number 2 in cytotype B) indicates the need for morphometric and electrophoretic studies for further characterization of the two registered subspecies.

The above considerations suggests the possibility of a further taxonomic subdivision for $O s$ goodomys banderanus, in a similar way as that followed by Baker et al. (1983) where they reported "chromosomic races" for Peromyscus leocopus. Lee et al. (1972) also contributed in a similar way to the specific recognition of Peromyscus attwateri through their studies on the chromosomic variation within the populations of Peromyscus boylii.

Cytotypes $\mathrm{C}$ and D suggest that $O$. banderanus populations have had the opportunity since its early origin of a radiation with an impact on their karyotype. Therefore, it would be desirable to study the reproductive aspects within these populations, as has been suggested by Zimmerman et al. (1978) in order to clarify taxonomic doubts.

From the analysis of the chromosomic material, no evidence was found that suggests inbreeding between the different cytotypes. Therefore, it is possible that there is some reproductive isolation, which supports the presence of different taxons in a similar manner to that proposed by Hinesley (1979). The idea of reproductive isolation is reinforced by the integrity of $\mathrm{B}$ or $\mathrm{C}$ karyotypes populations in spite of the fact that the areas where the specimens for these karyotypes were captured were in close geographic proximity (Sierra Coalcoman north slope, state of Michoacán).

It is worth pointing out that the studied cytotypes that do not project detectable chromosomic variation come from localities far

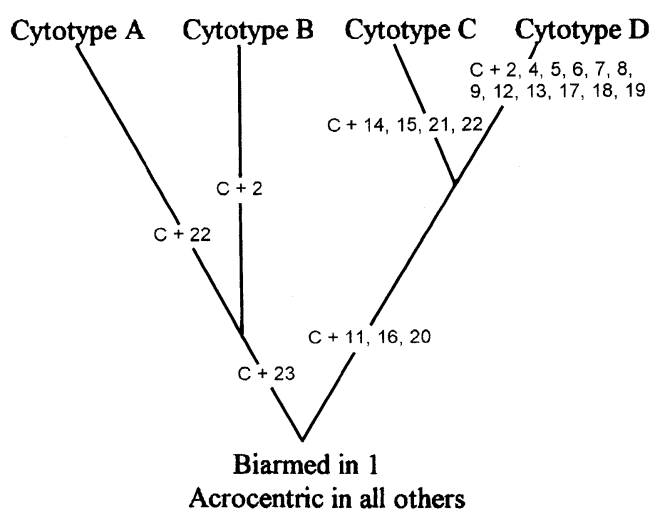

Fig. 4. Cladogram showing most parsimoniosus routes of additions of arms in chromosomes of found cytotypes in Osgoodomys banderanus populations. 
apart within the geographic area for those karyotypes, therefore, it is possible that both cytotypes have remained invariable throughout their distribution areas.

At this time, it is not possible to answer the question of whether the existence of 3 different cytotypes to that presently recognized for the species is indicative of the possible existence of populations not recognized in the literature.

The cladogram presented in Fig. 4 shows the most parsimonious route for the additions of chromosomic arms in $O$. banderanus. This requires 20 events in order to produce cytotypes $\mathrm{B}, \mathrm{C}$, and D, starting from cytotype A which is recognized as the primitive one. (Committee 1977, Greenbaum and Baker 1978, Baker et al. 1979, Yates et al. 1979, Robbins and Baker 1981, Rogers et al. 1984, Stangl Jr. and Baker 1984).

\section{Acknowledgments}

Authors wish to acknowledge to: A Rocío Ortíz Muñiz and Robert D. Bradley for their comments and suggestions; Rosa María González Monroy, Edith Cortés Barberena and Patricia Pérez Vera, for their skillfull assistance in the handling of chromosomic material, to Martín Sandoval Rangel, for his assistance in the field and Alan Richards Lewis for correcting the English.

\section{References}

Allen, J. A. 1897. Further notes on mammals collected in Mexico by Dr. Audley C. Buller, with descriptions on new species. Bull. Amer. Mus. Nat. Hist. 9: 47-58.

Alvarez, T. 1968. Notas sobre una colección de mamíferos de la región costera del Río Balsas entre Michoacán y Guerrero. Revista Soc. Mex. Hist. 29: 21-32.

Arrighi, G. E., Stock, A. D. and Pathak, S. 1976. Chromosomes of Peromyscus (Rodentia: Cricetidae) V. Evidence of pericentric inversions. Chromosomes Today 5: 323-329.

Baker, R. J., Barnett, R. K. and Greebaum, I. F. 1979. Chromosomal evolution in grasshopper mice (Onychomys, Cricetidae). J. Mamm. 60: 297-306.

-, Koop, B. F. and Haiduk, M. W. 1983. Resolving systematics relationships with G-bands: A study of five genera of South American Cricetine rodents. Syst. Zool. 32(4): 403-416.

-, Qumsiyeh, M. B. and Hood, C. S. 1987. Role of Chromosomal Banding Patterns in Understanding Mammalian Evolution. In: Genoways, H. (ed.) Current Mammalogy, Plenum Publ. Corporation. 1: 67-96.

Carleton, M. D. 1980. Phylogenetic relationships in Neotomine-Peromyscine rodents (Muroidea) and a reappraisal of the dichotomy within New World cricetinae. Misc. Publ., Museum Zoology, Univ. Michigan 157: 23.

- 1989. Systematics and Evolution pp. 7-141. In: Kirkland Jr., J. G. and Layne, J. N. (ed.) Advances in the Study of Peromyscus. Texas Tech Univ. Press. 367 pp.

Committee for Standardization of Chromosomes of Peromyscus. 1977. Standardized karyotype of deer mouse, Peromyscus (Rodentia). Cyto. Cell Genetics 19: 38-43.

- 1994. Citogenetics nomenclature of deer mice, Peromyscus (Rodentia): Revision and review of the standarized karyotype: Cyto. Cell Genetics 66(3): 181-195.

Dyer, A. F. 1979. Finding Chromosomes - a matter of method. In: Investigating Chromosomes. E. Arnold Publisher, Londres. $34 \mathrm{p}$.

Greenbaum, I. F. and Baker, R. J. 1978. Determination of the primitive karyotype for Peromyscus. J. Mamm., 59(4): 820834.

Hall, E. R. 1981. The Mammals of North America. John Wiley and Sons. U.S.A. 2: 721.

Hinesley, L. L. 1979. Systematics and distribution of two chromosomes forms in the southern grasshopper mouse, genus Onychomys. J. Mamm. 60(1): 117-128.

Hooper, E. T. 1958. The male phallus in mice of the genus Peromyscus. Misc. Publ. Museum Zoology, Univ. Michigan, 105: $1-24$.

- 1968. Classification. pp. 27-74, In: King, J. A. (ed.). Biology of Peromyscus (Rodentia). Special Publication, Amer. Soc. of Mamm. 2: 1-593.

— and Musser, G. G. 1964. Notes on clasification on the rodent genus Peromyscus. Occas. Papers Museum Zoology, Univ. Michigan, 635: 1-13.

Hsu, T. C. and Arrighi, F. E. 1968. Chromosomes of Peromyscus (Rodentia: Cricetidae) I. Evolutionary trends in 20 
species. Cytogenetics 7: 417-446.

Lawlor, T. E. 1974. Chromosomal evolution in Peromyscus. Evolution 28: 689-692.

Lee, M. R. and Elder, F. F. 977. Karyotypes of eight species of Mexican rodents: Muridae. J. Mamm. 68: 479-487.

- Schmidly, D. J. and Huheey, C. C. 1972. Chromosomal variation in certain populations of Peromyscus boylii and its systematics implications. J. Mamm. 53(4): 697-704.

Levan, A., Fredga, K. and Sandberg, A. 1964. Nomenclature for centromeric position on chromosomes. Hereditas 52: 201220.

Linzey, A. B. and Layne, J. N. 1969. Comparative morphology of the male reproductive tract in the rodent genus, Peromyscus (Muridae). Amer. Mus. Novitates 2355: 1-47.

Núñez, G. A. 1993. Sistemática y distribución del género Peromyscus (Rodentia: Cricetidae) en el estado de Michoacán, México. Sc. Master Thesis Fac. de Ciencias, U.N.A.M. México, D.F. 126 p.

Robbins, L. W. and Baker, R. J. 1981. An assessment of the nature rearrangements in eighteen species of Peromyscus (Rodentia: Cricetidae). Citogenet. Cell Genet. 31: 194-202.

Rogers, D. S., Greenbaum, I. F., Gunn, S. J. and Engstrom, M. D. 1984. Cytosystematic value of chromosomal inversion data in the genus Peromyscus (Rodentia: Cricetidae). J. Mamm. 65(3): 457-465.

Stangl Jr., F. B. and Baker, R. J. 1984. Evolutionary relationships in Peromyscus: Congruence in chromosomal, genic and classical data sets. J. Mamm. 65(4): 643-654.

Yates, T. L., Baker, R. J. and Barnett, P. K. 1979. Philogenetic analysis of karyological variations in three genera of peromyscine rodents. Systematic Zoology 28: 40-48.

Zimmerman, E. G., Kilpatrick, W. and Hart, B. J. 1978. The genetics of speciation in the rodent genus Peromyscus. Evolution 32(3): 565-579.

Specimens examined (76) Specific localities for specimens of Osgoodomys banderanus examined in this study: Colima.-2 -2 : E1 Sauz, $8 \mathrm{~km}$ NE Minatitlán, 1,200 m $\left(19^{\circ} 26^{\prime} 16^{\prime \prime} \mathrm{N}, 104^{\circ} 01^{\prime} \mathrm{W}\right) ; 10^{\star}, 2$ \%: $7 \mathrm{~km}$ SW Minatitlan, $780\left(19^{\circ} 26^{\prime} 45^{\prime \prime} \mathrm{N}, 104^{\circ} 06^{\prime} 09^{\prime \prime} \mathrm{W}\right) ; 20^{\circ}: 9 \mathrm{~km} \mathrm{SW}$ Minatitlan, $810 \mathrm{~m}\left(19^{\circ} 19^{\prime} 45^{\prime \prime} \mathrm{N}, 104^{\circ} 06^{\prime} 50^{\prime \prime} \mathrm{W}\right) ; 1$; E1 Salto $4 \mathrm{~km}$ WSW Minatitlán, $630 \mathrm{~m}\left(19^{\circ} 22^{\prime} 09^{\prime \prime \prime} \mathrm{N}, 104^{\circ} 05^{\prime} 08^{\prime \prime} \mathrm{W}\right)$; $60^{\circ}, 19: 3.4 \mathrm{~km} \mathrm{SW}$ Las Canoas, $550 \mathrm{~m}$ $\left(19^{\circ} 13^{\prime} 50^{\prime \prime} \mathrm{N}, 104^{\circ} 07^{\prime} 10^{\prime \prime} \mathrm{W}\right)$; $10^{\circ}, 19: 2.6 \mathrm{~km}$ SSE Las Canoas, $630 \mathrm{~m}\left(19^{\circ} 13^{\prime} 38^{\prime \prime} \mathrm{N}, 104^{\circ} 08^{\prime} 08^{\prime \prime} \mathrm{W}\right) ; 20^{\circ}, 1 q^{\circ}$ : $3.9 \mathrm{~km}$ NE Las Conchs, $73 \mathrm{~m}\left(18^{\circ} 54^{\prime} 25^{\prime \prime} \mathrm{N}, 103^{\circ} 36^{\prime} 16^{\prime \prime} \mathrm{W}\right) ; 30^{\prime}: 4.3 \mathrm{~km}$ NE Las Conchas, $133 \mathrm{~m}\left(18^{\circ} 54^{\prime} 37^{\prime \prime} \mathrm{N}\right.$,

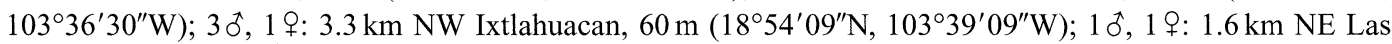
Conchas, $50 \mathrm{~m}\left(18^{\circ} 54^{\prime} 15^{\prime \prime} \mathrm{N}, 103^{\circ} 36^{\prime} \mathrm{W}\right)$. Michoacan.-3 $0^{\circ}, 3$ \% : $1 \mathrm{~km} \mathrm{~N}$ E1 Infiernillo $\left(18^{\circ} 15^{\prime} \mathrm{N}, 101^{\circ} 54^{\prime} \mathrm{W}\right)$; $3 \delta^{\prime}, 1$ ㅇ: $2 \mathrm{~km} \mathrm{~N}$ Caleta de Campos $\left(18^{\circ} 05^{\prime} \mathrm{N}, 102^{\circ} 46^{\prime} \mathrm{W}\right) ; 10^{\dagger}: 2 \mathrm{~km}$ W Cerro Colorado, $1,113 \mathrm{~m}\left(19^{\circ} 15^{\prime} \mathrm{N}\right.$, $\left.100^{\circ} 21^{\prime} \mathrm{W}\right) ; 10^{\dagger}, 1$ \%: La Yácata island, $5.12 \mathrm{~km}$ NNE Puerto Platanitos, $270 \mathrm{~m}\left(18^{\circ} 40^{\prime} 10^{\prime \prime} \mathrm{N}, 101^{\circ} 52^{\prime} 24^{\prime \prime} \mathrm{W}\right)$;

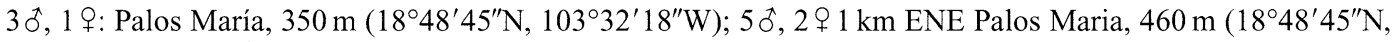
$\left.103^{\circ} 31^{\prime} 29^{\prime \prime} \mathrm{W}\right) ; 3 \delta^{\circ}, 1$ ㅇ: $1 \mathrm{~km}$ NE Palos María, $380 \mathrm{~m}\left(18^{\circ} 48^{\prime} 47^{\prime \prime} \mathrm{N}, 103^{\circ} 32^{\prime} 12^{\prime \prime} \mathrm{W}\right) ; 50^{\dagger}, 5$ ㅇ: Chorros del Varal, $950 \mathrm{~m}\left(19^{\circ} 35^{\prime} \mathrm{N}, 102^{\circ} 36^{\prime} \mathrm{W}\right) ; 1$ \% : $3 \mathrm{~km}$ E La Soledad, $9 \mathrm{~km}$ SE Jungapeo, 1,150 m $\left(19^{\circ} 26^{\prime} \mathrm{N}, 100^{\circ} 29^{\prime} \mathrm{W}\right) ; 2 \delta^{\prime}$, 1 9 : Los Manguitos, $8.8 \mathrm{~km}$ ESE Dos Aguas, $1,440 \mathrm{~m}\left(18^{\circ} 46^{\prime} 01^{\prime \prime} \mathrm{N}, 102^{\circ} 51^{\prime} \mathrm{W}\right)$. Nayarit.-1 $\delta^{\circ}, 1 \%: 7.6 \mathrm{~km}$ ENE San Blas, $60 \mathrm{~m}\left(21^{\circ} 34^{\prime} 28^{\prime \prime} \mathrm{N}, 105^{\circ} 13^{\prime} 06^{\prime \prime} \mathrm{W}\right) ; 20^{\circ}, 1$ \% : Arroyo La Quebrada $4.5 \mathrm{~km} \mathrm{~W}$ Valle de Banderas, $120 \mathrm{~m}\left(20^{\circ} 48^{\prime} 06^{\prime \prime} \mathrm{N}, 105^{\circ} 17^{\prime} 12^{\prime \prime} \mathrm{W}\right)$. 